\title{
Susceptibility of onion cultivars to infection by pathogenic bacteria
}

\section{Podatność odmian cebuli na porażenie przez patogeny bakteryjne}

\author{
Beata Kowalska, Urszula Smolińska
}

\section{Summary}

There is limited information about the resistance of onion cultivars to bacterial diseases registered in Poland. Therefore, in the presented work 33 varieties of onion were examined for their susceptibility to infection by Burkholderia cepacia, B. gladioli pv. alliicola and Pectobacterium carotovorum subsp. carotovorum. It was found that most of the studied cultivars were sensitive to infection by $B$. cepacia. In the case of $P$. carotovorum subsp. carotovorum and B. gladioli pv. alliicola the susceptibility of studied cultivars varied. Alonso $F_{1}$ cultivar showed the highest resistance to bacterial infection.

Key words: susceptibility; onion; pathogenic bacteria

\section{Streszczenie}

W wykazie zarejestrowanych w Polsce odmian cebuli brak jest informacji na temat ich odporności na choroby bakteryjne. W ramach pracy przebadano podatność 33 odmian na porażenie przez Burkholderia cepacia, B. gladioli pv. alliicola i Pectobacterium carotovorum subsp. carotovorum. Niemal wszystkie odmiany były wrażliwe na porażenie przez $B$. cepacia. Większe zróżnicowanie w podatności między odmianami obserwowano w przypadku porażenia przez $P$. carotovorum subsp. carotovorum i B. gladioli pv. alliicola. Odmiana Alonso $F_{1}$ wykazała najmniejszą podatność na porażenie przez wszystkie badane bakterie.

Słowa kluczowe: podatność; cebula; bakterie patogeniczne

\author{
Instytut Ogrodnictwa \\ Pracownia Mikrobiologil \\ Konstytucji 3 Maja 1/3, 96-100 Skierniewice \\ Beata.Kowalska@inhort.pl
}




\section{Wstęp / Introduction}

Polska jest od wielu lat jednym z głównych producentów cebuli (Allium cepa L.) w Europie, zajmując trzecie miejsce pod względem wielkości produkcji. Powierzchnia uprawy tego warzywa w kraju w 2012 roku wynosiła 25,1 tys. ha, zbiory cebuli - 642,2 tys. ton, a eksport około 120 tys. ton (Analizy rynkowe 2013). $\mathrm{Z}$ tego względu cebula należy do najważniejszych gatunków warzyw uprawianych w naszym kraju (Knaflewski 2007).

Od kilku lat w Polsce notuje się znaczny wzrost liczby chorób bakteryjnych na roślinach warzywnych. Poważne straty zauważalne są w uprawach polowych, w transporcie oraz szczególnie podczas przechowywania. Przyczyną nasilenia chorób bakteryjnych są między innymi warunki atmosferyczne - wysoka temperatura w okresie wegetacji warzyw, duże ilości opadów, gradobicia, silne wiatry i okresowe podtopienia pól. Ponadto, ze względu na brak wystarczająco skutecznych środków ochrony istnieją ogromne trudności w zapobieganiu tym chorobom. Bakteriozy rozwijają się bardzo szybko, a początkowy proces chorobowy jest trudno zauważalny. Cebula porażana jest przez następujące gatunki bakterii: Burkholderia gladioli pv. alliicola, B. cepacia, Pectobacterium carotovorum subsp. carotovorum, Pseudomonas marginalis pv. marginalis, $P$. viridiflava, P. fluorescens, $P$. aeruginosa, Serratia plymuthica, Enterobacter cloacae i Pantoea ananatis (Agrios 2005; Schwartz i Mohan 2008; Kowalska 2010).

Gatunek B. cepacia znany jest jako sprawca bakteriozy na cebuli, w literaturze zwanej kwaśną skórką. Choroba ta stanowi poważny problem w warzywnictwie, gdyż prowadzi do dużych strat w plonie cebuli, czasami sięgających nawet 50\% (Schwartz i Mohan 2008). Zniszczenia spowodowane przez tę bakterię zauważalne są często dopiero w przechowalniach, mimo że infekcja cebul występuje już na polu. Patogen obecny w glebie lub wodzie wnika do tkanek poprzez zranienia w okolicy szyjki lub na liściach, powstałe np. po załamaniu szczypioru lub wskutek mechanicznego uszkodzenia (Kawamoto i Lorbeer 1974) i przemieszcza się w tkankach szczypioru w kierunku główki cebuli. Zewnętrzne łuski stają się śluzowate, przybierają zabarwienie od jasnożółtego do jasnobrązowego. Wewnętrzne łuski oraz środkowa część cebuli pozostają niezasiedlone. Suche zewnętrzne łuski mogą łatwo ulec oddzieleniu podczas ręcznego wyrywania cebul, ukazując porażoną część cebuli. Temperatura sprzyjająca rozwojowi choroby to ponad $30^{\circ} \mathrm{C}$. Czasami, szczególnie u młodych roślin, infekcja pozostaje utajona, a symptomy pojawiają się, gdy zaczyna tworzyć się cebula (Sobiczewski i Schollenberger 2002; Schwartz i Mohan 2008).

B. gladioli pv. alliicola jest sprawcą miękkiej zgnilizny cebuli zaczynającej się od szyjki. Choroba ta często jest następstwem uszkodzeń szyjki, spowodowanych przez inne patogeny, np. Peronospora destructor lub przez czynniki atmosferyczne, np. grad. W latach obfitujących w deszcze, bakterioza może być obserwowana w końcowym etapie uprawy cebuli. We wczesnym stadium na powierzchni cebuli nie występują żadne widoczne zmiany, oprócz czasami miękkiej szyjki zauważalnej po naciśnięciu. Na przekroju można zaobserwować jedną lub dwie porażone wewnętrzne łuski mięsiste. Są one miękkie i wyglądają jak nasiąknięte wodą. Z czasem na gnijących łuskach pojawiają się ciemne przebarwienia oraz dochodzi do mięknięcia i gnicia całej cebuli.

Bakteria P. carotovorum subsp. carotovorum wywołuje na cebuli mokrą zgniliznę. Początkowe objawy to małe plamki, wyglądające jakby były nasiąknięte wodą, które gwałtownie powiększają się i występują zarówno na powierzchni, jak i przenikają w głąb penetrowanej tkanki. Tkanka w obrębie porażonego fragmentu staje się kremowo zabarwiona, śluzowata i przekształca się w lekko ziarnistą masę. Powierzchnia porażonych cebul może pozostać nieuszkodzona, podczas gdy wewnętrzne tkanki zmieniają się w mętną, półpłynną papkę. $\mathrm{Z}$ czasem cała cebula może ulec przekształceniu w miękką, wodnistą, zgniłą masę. $\mathrm{Z}$ gnijących tkanek wydziela się odrażający zapach. Często jest on wynikiem rozkładu tkanki przez wtórnie wnikające bakterie saprotroficzne (Sobiczewski i Schollenberger 2002).

Jedną ze skutecznych metod ochrony roślin przed chorobami jest uprawa odmian roślin odpornych. Rośliny mogą wykazywać odporność na różnym poziomie. Roślina może być całkowicie odporna, to znaczy immunna, czyli niezakażalna. Immunia to jeden biegun odporności. Drugi biegun to wysoka podatność występująca wtedy, kiedy roślina nie ma żadnych cech odporności, więc nie może w żaden sposób przeciwstawić się patogenowi i reaguje silnymi objawami na jego obecność. Między tymi biegunami występuje cała gama reakcji pośrednich. Roślina może być częściowo odporna czy też mniej podatna niż inne rośliny. Może ona trudniej ulegać zakażeniu, patogen może wolniej ją opanowywać, wolniej się w niej rozmnażać, a pojawiające się objawy mogą nie być tak silne (Alvarez i wsp. 2010).

Odporność roślin warzywnych na bakteriozy stanowi istotną informację charakteryzującą daną odmianę. Jednakże w obecnym wykazie zarejestrowanych odmian cebuli brak jest takich informacji (Gacek 2012).

Badania nad odpornością cebuli na porażenie przez bakterie prowadzili Schroeder i wsp. (2009). Przeanalizowali oni ponad 60 odmian pod względem ich podatności na porażenie przez E. cloacae i stwierdzili zróżnicowaną odporność uzależnioną od odmiany.

Celem pracy była ocena podatności wybranych odmian cebuli ( $A$. серa) na porażenie przez bakterie $B$. cepacia, $B$. gladioli pv. alliicola i $P$. carotovorum subsp. carotovorum.

\section{Materiały i metody / Materials and methods}

Doświadczenie prowadzono w warunkach laboratoryjnych. Materiałem do badań były cebule różnych odmian uzyskane ze Stacji Doświadczalnej Centralnego Ośrodka Badania Odmian Roślin Uprawnych (COBORU) w Lućmierzu (Bonus $\mathrm{F}_{1}$, Cymes, Cyklop, Dakota $\mathrm{F}_{1}$, Fireball $\mathrm{F}_{1}$, Golden Spike $F_{1}$, Ławica, Majka, Otylia, Polanowska, Redmate, REO $550 \mathrm{~F}_{1}$, Scarlet, Sherpa $\mathrm{F}_{1}$, Takstar $\mathrm{F}_{1}$, Tęcza, Wenta, Zeta, Zorza), z Rolniczej Spółdzielni 
Produkcyjnej $\mathrm{w}$ Hopkie (Alonso $\mathrm{F}_{1}$, Armstrong $\mathrm{F}_{1}$, Drago $F_{1}$, Hyline $F_{1}$, Narvito $F_{1}$, Vision $F_{1}$ ) oraz $z$ Pola Doświadczalnego Instytutu Ogrodnictwa (Canto $F_{1}$, Durco $F_{1}$, Hybelle $F_{1}$, Hyfort $F_{1}$, Napoleon $F_{1}$, Red Baron, Sprinter $F_{1}$, Wellington $F_{1}$ ). $Z$ cebul usunięto zewnętrzne, suche łuski, cebule opłukano pod bieżącą wodą i poddano sterylizacji w 70\% alkoholu etylowym przez 30 sekund i w $0,5 \% \mathrm{NaOCl}$ przez 5 minut. Następnie przepłukano je w jałowej wodzie destylowanej. Cebule krojono podłużnie na dwie części i po trzy takie części umieszczano w jałowej szalce o średnicy $19 \mathrm{~cm}$, na bibule filtracyjnej nasączonej wodą. Cebule uszkadzano punktowo igłą preparacyjną (średnica $1,0-1,5 \mathrm{~mm}$ ) i inokulowano $20 \mu \mathrm{l}$ zawiesiny bakteryjnej o gęstości 1,0-2,5 x $10^{8} \mathrm{jtk} / \mathrm{ml}$. Do badań wykorzystano szczepy wzorcowe bakterii: $P$. carotovorum subsp. carotovorum NCPPB 1747, B. cepacia LMG 6962 oraz B. gladioli pv. alliicola LMG 6979, które uzyskano z Banku Patogenów w Belgii. Po przeprowadzeniu pierwszej serii doświadczenia dla bakterii $B$. cepacia i B. gladioli pv. alliicola zmniejszono gęstość stosowanej zawiesiny do inokulacji łusek cebuli odpowiednio do około $2,0-4,0 \times 10^{6} \mathrm{jtk} / \mathrm{ml} \mathrm{i} 2,0-4,0 \times 10^{7} \mathrm{jtk} / \mathrm{ml}$. Szalki umieszczano w komorze inkubacyjnej w temperaturze $28^{\circ} \mathrm{C}$, w ciemności. Ocenę zdrowotności łusek prowadzono po 6 dniach inkubacji. Mierzono średnicę porażonej części cebuli. Dla każdej odmiany i każdej bakterii wykonano po dwa powtórzenia (2 szalki). Dla każdej odmiany kombinację kontrolną stanowiły cebule, gdzie na uszkodzone miejsce nakraplano $20 \mu \mathrm{l}$ sterylnej wody. Miało to na celu sprawdzenie prawidłowości przeprowadzonych doświadczeń inokulacyjnych i wykluczenie ewentualnych zakażeń latentnych.

Doświadczenie przeprowadzono dwukrotnie, przez dwa kolejne lata.

Wyniki opracowano za pomocą analizy wariancji. Do porównania średnich stosowano test Newmana-Keulsa $(\alpha<0,05)$.

\section{Wyniki i dyskusja / Results and discussion}

W badaniach nie wykazano różnic w podatności 19 odmian uzyskanych z COBORU oraz 8 odmian uzyskanych

Tabela 1. Podatność odmian cebuli uzyskanych ze Stacji Doświadczalnej (Lućmierz) na porażenie przez B. cepacia, B. gladioli pv. alliicola i $P$. carotovorum subsp. carotovorum

Table 1. Susceptibility of onion cultivars obtained from Research Centre for Cultivar Testing (Lućmierz) to infection by B. cepacia, B. gladioli pv. alliicola and P. carotovorum subsp. carotovorum

\begin{tabular}{|c|c|c|c|}
\hline \multirow{2}{*}{$\begin{array}{l}\text { Odmiana } \\
\text { Cultivar }\end{array}$} & \multirow{2}{*}{$\begin{array}{l}\text { Procent porażenia łuski } \\
\text { Percent of infected scale } \\
\text { B. cepacia }\end{array}$} & \multicolumn{2}{|c|}{$\begin{array}{l}\text { Średnica porażonej tkanki łuski }[\mathrm{mm}] \\
\text { Diameter of infected tissue scale }[\mathrm{mm}]\end{array}$} \\
\hline & & $\begin{array}{l}\text { B. gladioli } \\
\text { pv. alliicola }\end{array}$ & $\begin{array}{l}\text { P. carotovorum } \\
\text { subsp. carotovorum }\end{array}$ \\
\hline Bonus $\mathrm{F}_{1}$ & 100 & $56,2 \mathrm{a}$ & 14,8 bcde \\
\hline Cymes & 100 & 31,7 bcde & $7,8 \mathrm{cde}$ \\
\hline Cyklop & 100 & 27,0 cde & 14,5 bcde \\
\hline Dakota $F_{1}$ & 100 & 28,5 cde & $11,3 \mathrm{cde}$ \\
\hline Fireball $\mathrm{F}_{1}$ & 100 & $22,0 \mathrm{de}$ & 19,3 bcde \\
\hline Golden Spike $F_{1}$ & 100 & 31,3 bcde & 22,8 bcde \\
\hline Lawica & 100 & $42,2 \mathrm{abc}$ & $37,5 \mathrm{ab}$ \\
\hline Majka & 100 & $43,8 \mathrm{abc}$ & $10,5 \mathrm{cde}$ \\
\hline Otylia & 100 & $22,3 \mathrm{de}$ & $28,2 \mathrm{bcd}$ \\
\hline Polanowska & 100 & 29,0 cde & $4,7 \mathrm{de}$ \\
\hline REO $550 \mathrm{~F}_{1}$ & 100 & $43,3 \mathrm{abc}$ & 24,2 bcde \\
\hline Redmate & 100 & 33,5 bcde & $29,0 \mathrm{bcd}$ \\
\hline Scarlet & 100 & $15,8 \mathrm{e}$ & $39,0 \mathrm{ab}$ \\
\hline Sherpa $F_{1}$ & 100 & $39,5 \mathrm{abcd}$ & 20,7 bcde \\
\hline Takstar $\mathrm{F}_{1}$ & 100 & $57,3 \mathrm{a}$ & 18,3 bcde \\
\hline Tęcza & 100 & $45,3 \mathrm{abc}$ & 5,8 cde \\
\hline Zeta & 100 & $53,5 \mathrm{a}$ & $53,2 \mathrm{a}$ \\
\hline Zorza & 100 & $50,0 \mathrm{ab}$ & $32,5 \mathrm{bc}$ \\
\hline Wenta & 100 & $42,7 \mathrm{abc}$ & 10,3 cde \\
\hline $\begin{array}{l}\text { Kontrola - Control } \\
\text { Cebula nieinokulowana } \\
\text { Uninfected onion }\end{array}$ & 0 & $0,0 \mathrm{f}$ & $0,0 \mathrm{e}$ \\
\hline
\end{tabular}

Liczby w kolumnach oznaczone tymi samymi literami nie różnią się istotnie według testu Newmana-Keulsa $(\alpha<0,05)$

Means in the same column followed by the same letter do not differ significantly according to Newman-Keuls $(\alpha<0.05)$ test 
Tabela 2. Podatność odmian cebuli uzyskanych z Pola Doświadczalnego Instytutu Ogrodnictwa na porażenie przez bakteryjne patogeny

Table 2. Susceptibility of onion cultivars obtained from Experimental Field in Institute of Horticulture to infection by $B$. cepacia, B. gladioli pv. alliicola and $P$. carotovorum subsp. carotovorum

\begin{tabular}{l|c|c|c}
\hline \multirow{2}{*}{$\begin{array}{c}\text { Odmiana } \\
\text { Cultivar }\end{array}$} & $\begin{array}{c}\text { Procent porażenia huski } \\
\text { Percent of infected scale }\end{array}$ & \multicolumn{2}{c}{$\begin{array}{c}\text { Średnica porażonej tkanki luski [mm] } \\
\text { Diameter of infected tissue scale [mm] }\end{array}$} \\
\cline { 2 - 4 } & B. cepacia & $\begin{array}{c}\text { B. gladioli } \\
\text { pv. allicola }\end{array}$ & $\begin{array}{c}\text { P. carotovorum } \\
\text { subsp. carotovorum }\end{array}$ \\
\hline Hybelle $\mathrm{F}_{1}$ & 100 & $18,7 \mathrm{a}$ & $3,5 \mathrm{~b}$ \\
\hline Sprinter $\mathrm{F}_{1}$ & 100 & $28,3 \mathrm{a}$ & $5,5 \mathrm{~b}$ \\
\hline Canto $\mathrm{F}_{1}$ & 100 & $22,3 \mathrm{a}$ & $27,0 \mathrm{a}$ \\
\hline Napoleon $\mathrm{F}_{1}$ & 100 & $7,8 \mathrm{~b}$ & $12,5 \mathrm{ab}$ \\
\hline Wellington $\mathrm{F}_{1}$ & 100 & $32,1 \mathrm{a}$ & $5,3 \mathrm{~b}$ \\
\hline Hyfort $\mathrm{F}_{1}$ & 100 & $22,1 \mathrm{a}$ & $4,8 \mathrm{~b}$ \\
\hline Durco $\mathrm{F}_{1}$ & 100 & $32,0 \mathrm{a}$ & $32,4 \mathrm{a}$ \\
\hline Red Baron & 100 & $33,2 \mathrm{a}$ & $25,3 \mathrm{a}$ \\
\hline $\begin{array}{l}\text { Kontrola }- \text { Control } \\
\text { Cebula nieinokulowana }\end{array}$ & 0 & $0,0 \mathrm{c}$ & $0,0 \mathrm{c}$ \\
\hline Uninfected onion & & & 2 \\
\hline
\end{tabular}

Liczby w kolumnach oznaczone tymi samymi literami nie różnią się istotnie według testu Newmana-Keulsa $(\alpha<0,05)$

Means in the same column followed by the same letter do not differ significantly according to Newman-Keuls $(\alpha<0.05)$ test

Tabela 3. Podatność odmian uzyskanych z Rolniczej Spółdzielni Produkcyjnej w Hopkie na porażenie przez patogeny bakteryjne

Table 3. Susceptibility of onion cultivars obtained from farming cooperatives in Hopkie to infection by B. cepacia, B. gladioli pv. alliicola and P. carotovorum subsp. carotovorum

\begin{tabular}{|c|c|c|c|}
\hline \multirow{2}{*}{$\begin{array}{l}\text { Odmiana } \\
\text { Cultivar }\end{array}$} & \multicolumn{3}{|c|}{$\begin{array}{c}\text { Średnica porażonej tkanki łuski } \\
\text { Diameter of infected tissue scale } \\
{[\mathrm{mm}]}\end{array}$} \\
\hline & B. cepacia & B. gladioli pv. alliicola & $\begin{array}{c}\text { P. carotovorum } \\
\text { subsp. carotovorum }\end{array}$ \\
\hline Alonso $\mathrm{F}_{1}$ & $7,7 \mathrm{~cd}$ & $1,7 \mathrm{c}$ & $5,8 \mathrm{~d}$ \\
\hline Armstrong $\mathrm{F}_{1}$ & $31,2 \mathrm{ab}$ & $19,3 \mathrm{a}$ & $29,5 \mathrm{a}$ \\
\hline Drago $F_{1}$ & $28,8 \mathrm{ab}$ & $7,2 \mathrm{bc}$ & $2,5 \mathrm{~d}$ \\
\hline Hyline $F_{1}$ & $35,7 \mathrm{a}$ & $23,3 \mathrm{a}$ & $22,8 \mathrm{~b}$ \\
\hline Narvito $F_{1}$ & $31,3 \mathrm{ab}$ & $10,0 \mathrm{~b}$ & $0,0 \mathrm{~d}$ \\
\hline Vision $\mathrm{F}_{1}$ & $15,5 \mathrm{bc}$ & $12,0 \mathrm{~b}$ & $16,3 \mathrm{c}$ \\
\hline $\begin{array}{l}\text { Kontrola - Control } \\
\text { Cebula nieinokulowana } \\
\text { Uninfected onion }\end{array}$ & $0,0 \mathrm{~d}$ & $0,0 \mathrm{c}$ & $0,0 \mathrm{~d}$ \\
\hline
\end{tabular}

Liczby w kolumnach oznaczone tymi samymi literami nie różnią się istotnie według testu Newmana-Keulsa $(\alpha<0,05)$

Means in the same column followed by the same letter do not differ significantly according to Newman-Keuls $(\alpha<0.05)$ test

z Pola Doświadczalnego Instytutu Ogrodnictwa na porażenie przez bakterię $B$. cepacia. Zarówno w pierwszej serii doświadczenia, kiedy stężenie inokulum wynosiło $1,0-2,5 \times 10^{8} \mathrm{jtk} / \mathrm{ml}$, jak również w drugiej serii doświadczenia przy stężeniu zmniejszonym do 2,0-4,0 $\times 10^{6} \mathrm{jtk} / \mathrm{ml}$ uzyskano wysoki stopień porażenia cebul, wynoszący dla wszystkich badanych odmian wartość zbliżoną do maksymalnej (tab. 1, 2). Odmiany uzyskane ze Spółdzielni Produkcyjnej w Hopkie wykazywały większe zróżnicowanie $\mathrm{w}$ podatności na porażenie przez tę bakterię. Najsłabsze nasilenie zmian chorobowych uzyskano na cebulach odmiany Alonso $F_{1} i$ Vision $F_{1}$ przy stężeniu inokulum wynoszącym 2,0-4,0 × $10^{6} \mathrm{jtk} / \mathrm{ml}$. Różnice te były istotne statystycznie $\mathrm{w}$ porównaniu do pozostałych odmian (tab. 3).
Większe zróżnicowanie $\mathrm{w}$ podatności odmian cebuli wykazano dla bakterii B. gladioli pv. alliicola oraz $P$. carotovorum subsp. carotovorum. Żadna $\mathrm{z}$ badanych odmian z COBORU nie była całkowicie odporna na testowane bakterie. Odmiany Scarlet, Otylia i Fireball $\mathrm{F}_{1}$ wykazały najmniejszą podatność na porażenie przez B. gladioli pv. alliicola. Średnica uzyskiwanych gnilnych plam na cebulach tych odmian wynosiła odpowiednio: 15,$8 ; 22,0$ i $22,3 \mathrm{~mm}$, podczas gdy dla odmiany najbardziej podatnej, np. Bonus $\mathrm{F}_{1}-56,2 \mathrm{~mm}$ (tab. 1). Dość dużą podatnością na porażenie przez $B$. gladioli pv. alliicola charakteryzowały się także odmiany: Zorza, Wenta, Tęcza, REO 550 F1, Majka i Ławica.

Zmiany chorobowe na cebulach odmian uzyskanych z COBORU, wywołane przez $P$. carotovorum subsp. 
carotovorum były znacznie mniejsze niż te powodowane przez szczepy Burkholderia. Niewielkie zmiany chorobowe obserwowano na cebulach odmiany Polanowska 4,7 mm oraz odmiany Cymes $-7,8 \mathrm{~mm}$, Dakota $\mathrm{F}_{1}$ - 11,3 mm, Majka - 10,5 mm, Tęcza - 5,8 mm, Wenta - 10,3 mm. Natomiast odmiany Zeta, Scarlet, Ławica wykazały wysoką podatność na porażenie przez $P$. $c a-$ rotovorum subsp. carotovorum (tab. 1).

Wśród odmian uzyskanych z Pola Doświadczalnego Instytutu Ogrodnictwa najmniejszą podatnością na zakażenie przez $B$. gladioli pv. alliicola charakteryzowała się odmiana Napoleon $F_{1}$. Odmiany Hybelle $F_{1}$, Sprinter $F_{1}$, Wellington $F_{1}$ i Hyfort $F_{1}$ były najmniej podatne na zakażenie przez $P$. carotovorum subsp. carotovorum. Żadna $\mathrm{z}$ badanych odmian nie była całkowicie odporna na badane bakterie (tab. 2).

Odmiany uzyskane ze Spółdzielni Produkcyjnej w Hopkie różniły się między sobą podatnością na porażenie przez $B$. cepacia, B. gladioli pv. alliicola i $P$. carotovorum subsp. carotovorum. Odmiana Narvito $\mathrm{F}_{1}$ wykazała całkowitą odporność na porażenie przez $P$. carotovorum subsp. carotovorum. Natomiast odmiana Alonso $\mathrm{F}_{1}$ wykazała istotnie mniejszą podatność na wszystkie trzy badane bakterie $\mathrm{W}$ porównaniu $\mathrm{z}$ pozostałymi odmianami (tab. 3).

W Polsce, jak również w innych krajach europejskich brak jest wystarczająco skutecznych środków ochrony warzyw przed chorobami wywoływanymi przez bakterie. $\mathrm{W}$ ostatnich latach $26 \% \mathrm{z}$ około 1000 substancji czynnych wchodzących w skład środków ochrony roślin, zostało wycofanych (Paaske 2009; Matyjaszczyk 2011). Obecnie w Polsce w zaleceniach Programu Ochrony Roślin brak jest zarejestrowanych środków do zwalczania bakterioz cebuli. W latach poprzednich producenci mogli stosować środki na bazie wyciagu $\mathrm{z}$ grejpfruta, ale zostały one wykreślone $\mathrm{z}$ listy środków dopuszczonych do stosowania.

$\mathrm{W}$ tej sytuacji jednym $\mathrm{z}$ najlepszych sposobów ograniczania chorób roślin uprawnych jest stosowanie odmian odpornych. Obecnie w krajowym rejestrze znajduje się 70 odmian cebuli (Gacek 2012). Stosunkowo niedawno wpisano do rejestru odmiany o czerwonej barwie łuski oraz nowe odmiany o białej suchej łusce. W ramach niniejszej pracy przebadano 33 odmiany cebuli pod względem ich podatności na porażenie przez referencyjne szczepy bakterii B. cepacia, B. gladioli pv. alliicola, $P$. carotovorum subsp. carotovorum. Wśród odmian były odmiany wczesne (np. Bonus $\mathrm{F}_{1}$, Majka), średnio wczesne (np. Cymes, Ławica, Napoleon $\mathrm{F}_{1}$ ), średnio późne (np. Polanowska, Sherpa $F_{1}$ ), późne (np. Armstrong $F_{1}$, Durco $\mathrm{F}_{1}$ ) oraz odmiany o czerwonej łusce (np. Redmate, Wenta, Scarlet). Niektóre odmiany zostały skreślone $\mathrm{z}$ rejestru w trakcie trwania badań, ponieważ upłynął z góry założony okres ważności.

Uzyskane w pracy wyniki wykazały, że badane odmiany cebuli istotnie różniły się między sobą podatnością na porażenie przez patogeniczne bakterie. Szczególnie duże zróżnicowanie wykazano w przypadku $B$. gladioli pv. alliicola i $P$. carotovorum subsp. caro- tovorum. Nie zauważono jednak zależności między podatnością a wczesnością odmian. Odmiana Zeta wykazała wysoką podatność na porażenie przez wszystkie badane patogeny (tab. 1). Alonso $\mathrm{F}_{1}$, odmiana o czerwonej łusce, jako jedyna spośród badanych wykazała istotnie najmniejszy stopień porażenia na wszystkie badane bakterie (tab. 3). Dla odmian uzyskanych z COBORU oraz z Pola Doświadczalnego Instytutu Ogrodnictwa nie wykazano różnic $\mathrm{w}$ podatności odmian na porażenie przez B. cepacia, wszystkie odmiany ulegały bardzo szybkiemu porażeniu (tab. 1, 2). Podobne wyniki uzyskali Schroeder i wsp. (2012), którzy zauważyli silniejszy rozwój zgnilizny na cebulach sztucznie zainokulowanych $B$. cepacia niż zainokulowanych $B$. gladioli pv. alliicola. Stwierdzono, że bakteria $B$. cepacia jest dużo bardziej agresywna niż B. gladioli pv. alliicola.

W literaturze niewiele jest publikacji na temat odporności odmian cebuli na porażenie przez bakterie. Przykładowo naukowcy z Uniwersytetu w Waszyngtonie testowali 69 odmian $A$. cepa pod względem ich podatności na porażenie przez E. cloacae podczas przechowywania cebul przez 4,5 miesiąca (Schroeder i wsp. 2010). Doświadczenie prowadzono przez dwa sezony przechowalnicze. Wykazano zróżnicowaną podatność odmian na porażenie przez E. cloacae. Odmiany czerwone okazały się być bardziej odporne na E. cloacae niż odmiany białe i żółte. Jednocześnie jednak odmiany te były częściej atakowane przez inne patogeny obecne na łuskach zewnętrznych.

Warto zaznaczyć, że wśród cech charakteryzujących odmiany cebuli nie ma informacji na temat ich odporności na porażenie przez bakterie (Gacek 2012). W sytuacji nasilenia chorób bakteryjnych w ostatnich latach w Polsce (Kowalska 2010), informacja taka miałaby istotne znaczenie w wyborze odmiany do uprawy przez producenta. Przedstawione $\mathrm{w}$ pracy wyniki dotyczące podatności odmianowej cebuli zostały uzyskane w badaniach laboratoryjnych. Wdrożenie ich do praktyki wymaga przeprowadzenia doświadczeń polowych i w przechowalniach.

\section{Wnioski / Conclusions}

1. Spośród 33 badanych odmian cebuli najmniejszą podatność na porażenie przez $B$. cepacia, B. gladioli pv. alliicola i $P$. carotovorum subsp. carotovorum wykazała odmiana Alonso $\mathrm{F}_{1}$.

2. Niemal wszystkie badane odmiany cebuli wykazywały wysoką podatność na porażenie przez B. cepacia.

Praca współfinansowana ze środków na naukę w latach 2008-2010 jako projekt badawczy promotorski nr NN 310299734. 


\section{Literatura / References}

Agrios G.N. 2005. Plant Pathology. Elsevier Academic Press: 615-703.

Alvarez M.E., Nota F., Cambiagno D.A. 2010. Epigenetic control of plant immunity. Mol. Plant Pathol. 11 (4): $563-576$.

Analizy rynkowe. Rynek owoców i warzyw. Stan i perspektywy. 2013. IERIGŻ-PIB, ARR, MRiRW, Warszawa, 42: $27-41$.

Gacek E.S. 2012. Lista opisowa odmian. Rośliny warzywne. Cebulowe. Cebula. Por. COBORU, Słupia Wielka, 52 ss.

Kawamoto S.O., Lorbeer J.W. 1974. Infectious of onions leaves by Pseudomonas cepacia. Phytopathology 64 (10): 1440-1445.

Knaflewski M. 2007. Ogólna uprawa warzyw. Wyd. PWRiL, Poznań, 405, 16 ss.

Kowalska B. 2010. Charakterystyka bakterii patogenicznych występujących na cebuli (Allium cepa L.) i metody ich zwalczania. Instytut Warzywnictwa, Skierniewice, 129 ss.

Matyjaszczyk E. 2011. Rejestracja środków ochrony roślin w Polsce - historia, stan obecny i przyszłość. [Registration of plant protection products in Poland - the history, present state and future]. Prog. Plant Prot./Post. Ochr. Roślin 51 (1): 77-87.

Paaske K. 2009. Pesticide legislation and effect on European production. p. 11. In: Proc.Onion Conference. Great Britain, November, $18-19,2009,44 \mathrm{pp}$

Schroeder B.K., Humann J.L., du Toit L.J. 2012. Effects of postharvest onion curing parameters on the development of sour skin and slippery skin in storage. Plant Dis. 96 (10): 1548-1555.

Schroeder B.K., du Toit L.J., Schwartz H.F. 2009. First report of Enterobacter cloacae causing onion bulb rot in the Columbia Basin of Washington State. Plant Dis. 93 (3), p. 323.

Schroeder B.K., Waters T.D., du Toit L.J. 2010. Evaluation of onion cultivars for resistance to Enterobacter cloacae in storage. Plant Dis. 94 (2): 236-243.

Schwartz H.F., Mohan S.K. 2008. Compendium of Onion and Garlic Diseases and Pests. APS Press, St. Paul, MN, 127 pp.

Sobiczewski P., Schollenberger M. 2002. Bakteryjne choroby roślin ogrodniczych. PWRiL, Warszawa, 156 ss. 